\title{
Occurrence of Aflatoxin in Some Food Commodities Commonly Consumed in Nigeria
}

\author{
I. O. Williams ${ }^{1}$, S. A. Ugbaje ${ }^{2}$, G. O. Igile ${ }^{1} \&$ O. O. $\mathrm{Ekpe}^{3}$ \\ ${ }^{1}$ Department of Biochemistry, University of Calabar, Calabar, Nigeria \\ ${ }^{2}$ Microbiology Laboratory, National Agency for Food and Drug Administration and Control (NAFDAC), Port \\ Harcourt, Nigeria \\ ${ }^{3}$ Ministry of Agriculture and Natural Resources, Calabar, Cross River State, Nigeria \\ Correspondence: I. O. Williams, Department of Biochemistry, University of Calabar, Calabar, Nigeria. Tel: \\ 234-803-501-8175. E-mail: imawills@yahoo.com
}

Received: February 26, 2015 Accepted: July 15, 2015 Online Published: August 27, 2015

doi:10.5539/jfr.v4n5p81 URL: http://dx.doi.org/10.5539/jfr.v4n5p81

\begin{abstract}
Aflatoxicosis is a public health problem in Nigeria like other tropical and sub-tropical regions of the world. Control of aflatoxin contamination requires thorough risk assessment, monitoring, quality control and empirical data. This study assayed total aflatoxin levels, identified and quantified four aflatoxin types in five food commodities commonly consumed in the six geopolitical zones of Nigeria. The food materials: Zea mays, Colocynthis citrullus, Capsicum frutescens, Irvingia gabonensis and Arachis hypogea were obtained from Watt market in Calabar urban. ELISA method was used for total aflatoxin, HPLC for aflatoxin types, AOAC for moisture. All $(100 \%)$ the samples were contaminated with aflatoxin. Contamination was highest in Irvingia gabonensis $(63.40 \pm 1.79 \mu \mathrm{g} / \mathrm{kg})$ and least in Zea mays $(3.20 \pm 0.12 \mu \mathrm{g} / \mathrm{kg})(\mathrm{p}<0.05)$. Except for Irvingia gabonensis and Colocynthis citrullus, total aflatoxin was within safe intake level of the Nigerian regulatory authority (National Agency for Food and Drug Adminstration and Control \{NAFDAC \}). All four aflatoxin types occurred in Irvingia gabonensis, Capsicum frutescens and Colocynthis citrullus; none was detected in Arachis hypogea. $\mathrm{AFB}_{1}$ contamination was highest in Irvingia gabonensis $(11.71 \pm 0.10 \mu \mathrm{g} / \mathrm{kg})$ followed by Capsicum frutescens $(1.21 \pm 0.01 \mu \mathrm{g} / \mathrm{kg}) ; \mathrm{AFB}_{2}$ ranged from $0.00 \pm 0.00-2.43 \pm 0.05 \mu \mathrm{g} / \mathrm{kg}, \mathrm{AFG}_{1} 0.00 \pm 0.00-3.73 \pm 0.04$ $\mu \mathrm{g} / \mathrm{kg}$, and $\mathrm{AFG}_{2} 0.00 \pm 0.00-0.54 \pm 0.01 \mu \mathrm{g} / \mathrm{kg}(\mathrm{p}<0.05)$. Only Irvingia gabonensis exceeded the limit of $\mathrm{AFB}_{1}$ specified by NAFDAC for human foods. Moisture content varied widely $(3.23 \pm 0.03 \%-10.37 \pm 0.19 \%)$. The trend in the occurrence of aflatoxins in the food samples was directly proportional $(\mathrm{r}=0.91)$ to their moisture contents. Food commodities sold in Calabar carry potential health hazard. Improved handling through food processing, preservation and storage can minimize aflatoxins in foodstuffs and ensure sustainable quality of food supply.
\end{abstract}

Keywords: aflatoxicosis, carcinogenicity, food safety, mycotoxigenic fungi, NAFDAC

\section{Introduction}

The safety of food and feed has been a major concern of nations especially in recent years as more knowledge is gathered on the occurrence of natural toxins in food stuffs, fertilizers, animal feed and edible plant materials. Naturally occurring toxins have been characterized by the World Health Organization (WHO, 2002) as significant sources of food borne illnesses. Of the natural food toxins, the Food and Agriculture Organization (FAO) has estimated that mycotoxins (fungal toxins) alone contaminate about $25 \%$ of agricultural products worldwide resulting in huge losses for farmers (Smith, Solomons, Lewis, \& Anderson, 1994; Wu, 2007). The biochemical properties of mycotoxins are diverse, and their toxic effects are exceedingly variable. Mycotoxins are carcinogenic, tremorogenic, haemorrhagic, genotoxic, teratogenic, nephrotoxic, hepatotoxic and immunotoxic (Refai, 1988; Hosseini \& Bagheri, 2012).

Out of the about 300 mycotoxins so far known, aflatoxin is the most studied, because of its common occurrence, high potency and toxicity to man and animals (SP-IPM, 2009). Aflatoxins are associated with high incidences of liver cancer in Africa and elsewhere and are thought to exacerbate diseases such as hepatitis B virus-induced liver cancer and HIV/AIDS (Shepherd, 2008). Other health effects of aflatoxins in animals and humans include 
reduced growth rate, weakened immune system and death (Eaton \& Groopman, 1994). At least thirteen (13) different types of aflatoxins are produced in nature with aflatoxin $\mathrm{B}_{1}$ considered as the most toxic and therefore of particular public health importance.

In recognition of the many dangers of aflatoxins, researchers and farmers around the world are seeking an understanding of how to manage the contamination dangers resulting from them. Meanwhile, policy makers are in the process of balancing food safety with food availability, a task requiring a thorough risk assessment and monitoring as well as empirical data. In view of the fact that foods from maize (Zea mays), melon seed (Colocynthis citrullus), ground nut (Arachis hypogea), bush mango (Irvingia gabonensis)and red pepper (Caspsicum frutescens) are consumed in a high rate in Nigeria, it is important to ensure that foods consumed are of premium quality of zero or minimal levels of aflatoxin and other contaminants. This is because people are as healthy as the food they eat. In addition to this, food adds to the economical income of man but unacceptable aflatoxin levels could pose a threat to this opportunity. This work was designed to assay for the aflatoxin contamination associated with some foodstuffs sold in Calabar urban with a view to enlightening the consumers on the need for proper food handling.

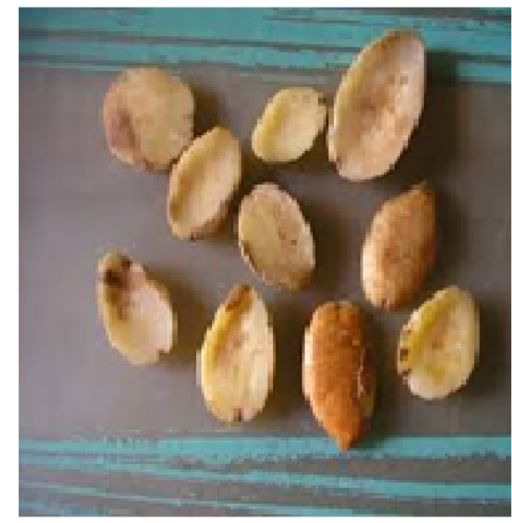

Figure 1. Irvingia gabonensis

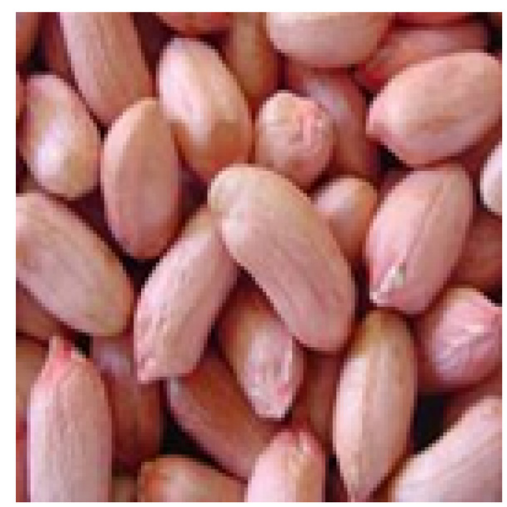

Figure 4. Arachis hypogea

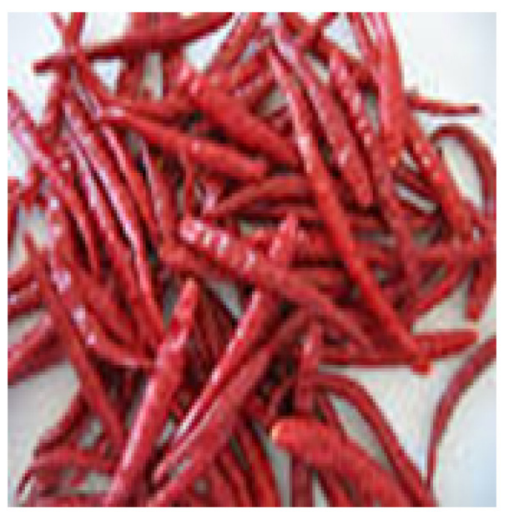

Figure 2. Caspsicum frutescens

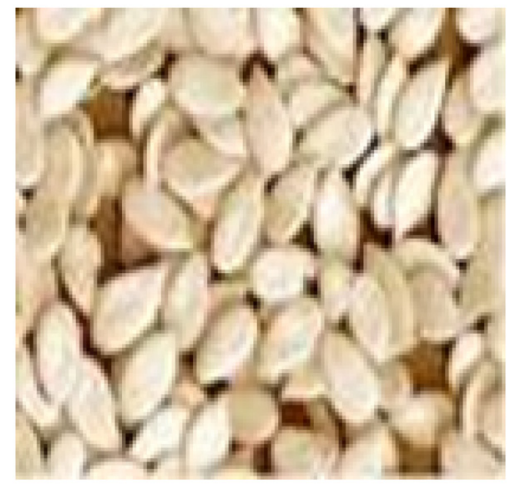

Figure 3. Colocynthis citrullus

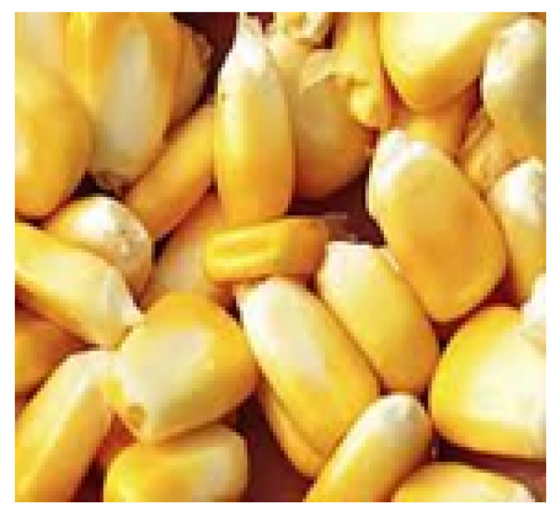

Figure 5. Zea mays

\section{Materials and Methods}

\subsection{Collection of Food Materials and Preliminary Preparation of Samples}

One (1) $\mathrm{kg}$ each of the five different food items: Zea mays (maize), Colocynthis citrullus, (melon seed), Caspsicum frutescens (red pepper), Irvingia gabonensis (bush mango) and Arachis hypogea (groundnut) were purchased in their dried forms from five different shops in Watt Market in Calabar urban in January, 2013. The food materials were transported to the Research Laboratory in the Department of Biochemistry, University of Calabar where all extraneous materials were removed. Each food material type was ground into powder and thoroughly mixed using a milling machine (MF-10 Basic IKA Werke, USA). Two (2) kg of each powdered 
sample was pooled and packaged in a sterile airtight self-adhesive polyethene pouch, labeled properly and stored in a glass chamber maintained under UV air sterilizer pending aflatoxin analysis and identification within 12 hours.

\subsection{Determination of Moisture Content}

The moisture content of each sample was determined using Automated Moisture Analyzer (Sartorius MA 150, Germany) as described by the Association of Official Analytical Chemists (AOAC, 2006). The method is based on loss of moisture upon drying at $105^{\circ} \mathrm{C}$.

\subsection{Preparation of Samples for Total Aflatoxin Analysis}

For the extraction of non-coloured samples, five hundred (500) g each of the samples of Zea mays and Colocynthis citrullus was weighed into a clean neogen cup, $1 \mathrm{~L}$ of distilled water was added and covered tightly. The samples were allowed to settle after which the top layer of the extract was filtered through a Whatman No. 1 filter paper $(150 \mathrm{~mm})$. The filtrate collected was then concentrated in a rotary evaporator (RE 300B Serial No. $\mathrm{R} 000010551, \mathrm{UK})$ in vacuo at $40 \pm 2{ }^{\circ} \mathrm{C}$ and used for total aflatoxin analysis.

For the extraction of naturally coloured samples, five hundred (500) g each of the composite samples of Capsicum frutescens, Irvingia gabonensis and Arachis hypogea was weighed into a clean neogen cup, $1.25 \mathrm{~L}$ of methanol/tween water (70:30) was added, covered tightly and placed on a laboratory shaker set at $250 \mathrm{rpm}$ for 3 minutes 30seconds. The samples were allowed to settle and the top layer of the extract filtered through a Whatman No. 1 filter paper $(150 \mathrm{~mm})$. The filtrate collected was then concentrated in the rotary evaporator in vacuo at $40 \pm 2{ }^{\circ} \mathrm{C}$ and used for total aflatoxin analysis.

\subsection{Determination of Total Aflatoxin}

Total aflatoxin content was determined using the AgraQuant assay kit (Romer Labs ${ }^{\circledR}$ Order No.COKAQ1100, Singapore). The AgraQuant assay kit procedure is based on a direct competitive enzyme-linked immunosorbent assay (ELISA) method as described by Ayar et al. (2007). The total aflatoxin concentration was read at $450-630$ $\mathrm{nm}$.

\subsection{Preparation of Samples for Identification and Quantification of Individual Aflatoxins}

Two hundred (200) g each of the samples was weighed into a $1 \mathrm{~L}$ conical flask and $500 \mathrm{ml}$ of $80 \%$ methanol was added and blended for 3 minutes. The homogenized sample was transferred into a $1 \mathrm{~L}$ conical flask and let to settle for 10 minutes. The supernatant layer was transferred into a $100 \mathrm{ml}$ centrifuge tube and centrifuged at 3000 rpm for 10minutes using a refrigerated centrifuge (Eppendorf AG 22331 Hamburg, Germany). The supernatant of the spun sample was transferred into a $500 \mathrm{ml}$ separating funnel, $50 \mathrm{ml}$ of $10 \% \mathrm{NaCl}$ solution was added, followed by $50 \mathrm{ml}$ hexane. The mixture was shaken for 1 minute and the organic layer discarded. To the aqueous layer collected, $50 \mathrm{ml}$ of dichloromethane was added and shaken for 2 minutes. The dichloromethane layer was then passed through anhydrous sodium sulphate to remove the traces of moisture. The dichloromethane extraction was repeated twice and the fractions were combined and evaporated in the rotary evaporator under vacuum at $40 \pm 2{ }^{\circ} \mathrm{C}$. This was transferred into a $5 \mathrm{ml}$ volumetric flask and made up to the mark with dichloromethane. Two (2) $\mathrm{ml}$ was drawn into a vial and evaporated in the rotary evaporator at $40 \pm 2{ }^{\circ} \mathrm{C}$. The residue was then taken for HPLC analysis.

\subsection{Identification and Quantification of Individual Aflatoxins}

The residue obtained from the concentrated extract was each dissolved in $1 \mathrm{ml}$ mobile phase and injected into the High Performance Liquid Chromatography (HPLC) column. A sensitive UV detector set at $365 \mathrm{~nm}$ was used to detect the aflatoxin types, which were eluted as sharp peaks within 4-7 minutes. The concentration of each aflatoxin type $\left(\mathrm{AFB}_{1}, \mathrm{AFB}_{2}, \mathrm{AFG}_{1}\right.$ and $\left.\mathrm{AFG}_{2}\right)$ was determined using the peak area ratios as described by $\mathrm{AOAC}$ (2006) and Herzallah (2009). The absorbance of each aflatoxin species was read at $365 \mathrm{~nm}$.

\subsection{Statistical Analysis}

The data obtained were subjected to analyses using the one-way analysis of variance (ANOVA) in SPSS statistical package; LSD was used for multiple comparisons. Statistical significance was accepted at $5 \%$ probability level or less.

\section{Results}

The Irvingia gabonensis sample had the highest $(10.37 \pm 0.19 \%)$, while Zea mays had the least $(3.23 \pm 0.03 \%)$ moisture content $(p<0.05)$. Low moisture content was also recorded in Colocynthis citrullus and Arachis hypogea ( $4.05 \pm 0.03 \%$ and $4.48 \pm 0.01 \%$ respectively); Capsicum frutescens had a moderate $(6.75 \pm 0.08 \%)$ 
level of moisture. The results also showed significantly different contents of total aflatoxin among the food commodities. Again, Irvingia gabonensis had the highest $(63.40 \pm 1.79 \mu \mathrm{g} / \mathrm{kg})$, while Zea mays had the least $(3.20 \pm 0.12 \mu \mathrm{g} / \mathrm{kg})$ total aflatoxin content. The total aflatoxin content in the other samples were: $8.00 \pm 0.06$ $\mu \mathrm{g} / \mathrm{kg}$ in Capsicum frutescens, $6.10 \pm 0.06 \mu \mathrm{g} / \mathrm{kg}$ in Colocynthis citrullus and $3.40 \pm 0.01 \mu \mathrm{g} / \mathrm{kg}$ in Arachis hypogea (Table1).

The aflatoxin concentrations in the five different foodstuffs evaluated correlated directly $(r=0.91)$ with the moisture contents in the foodstuffs (Figure 6).

Aflatoxin $\mathrm{B}_{1}\left(\mathrm{AFB}_{1}\right)$ concentration was significantly higher $(p<0.05)$ in Irvingia gabonensis $(11.71 \pm 0.10$ $\mu \mathrm{g} / \mathrm{kg}$ ) than the other four samples. $\mathrm{AFB}_{1}$ was $1.21 \pm 0.01 \mu \mathrm{g} / \mathrm{kg}$ in Capsicum frutescens, $0.82 \pm 0.02 \mu \mathrm{g} / \mathrm{kg}$ in Colocynthis citrullus but not detected in the Zea mays and Arachis hypogea samples. Similarly, Irvingia gabonensis had the highest $(p<0.05) \mathrm{AFB}_{2}$ content $(2.43 \pm 0.05)$. Other results for $\mathrm{AFB}_{2}$ were: $0.34 \pm 0.01 \mu \mathrm{g} / \mathrm{kg}$ in Capsicum frutescens, $0.05 \pm 0.01 \mu \mathrm{g} / \mathrm{kg}$ in Colocynthis citrullus, but not detectable in Zea mays and Arachis hypogea. The $\mathrm{AFG}_{1}$ was significantly $(p<0.05)$ higher in Capsicum frutescens $(3.73 \pm 0.04 \mu \mathrm{g} / \mathrm{kg})$ than in the other samples $(1.85 \pm 0.03 \mu \mathrm{g} / \mathrm{kg}$ in Irvingia gabonensis, $0.39 \pm 0.01 \mu \mathrm{g} / \mathrm{kg}$ in Colocynthis citrullus, and $0.19 \pm$ $0.01 \mu \mathrm{g} / \mathrm{kg}$ in Zea mays); Arachis hypogea did not show any detectable level of $\mathrm{AFG}_{1}$. The $\mathrm{AFG}_{2}$ was highest in Zea mays $(0.54 \pm 0.01 \mu \mathrm{g} / \mathrm{kg})(p<0.05)$ compared to the other four samples $(0.20 \pm 0.20 \mu \mathrm{g} / \mathrm{kg}$ in Capsicum frutescens, $0.14 \pm 0.01 \mu \mathrm{g} / \mathrm{kg}$ in Irvingia gabonensis and $0.09 \pm 0.00 \mu \mathrm{g} / \mathrm{kg}$ in Colocynthis citrullus). Again, $\mathrm{AFG}_{2}$ was not detected in Arachis hypogeal (Figure 7).

Table 1. Moisture and total aflatoxin contents of the food samples

\begin{tabular}{lll}
\hline Food samples & Moisture $(\%)$ & Total AFs $(\mu \mathrm{g} / \mathrm{kg})$ \\
\hline Zea mays & $3.23 \pm 0.03$ & $3.20 \pm 0.12$ \\
Colocynthis citrullus & $4.05 \pm 0.03^{*}$ & $6.10 \pm 0.06^{*}$ \\
Capsicum frutescens & $6.75 \pm 0.08^{*, \mathrm{a}}$ & $8.00 \pm 0.06^{*}$ \\
Irvingia gabonensis & $10.37 \pm 0.19^{*, \mathrm{a}, \mathrm{b}}$ & $63.40 \pm 1.79^{*, \mathrm{a}, \mathrm{b}}$ \\
Arachis hypogea & $4.48 \pm 0.01^{*, \mathrm{a}, \mathrm{b}}$ & $3.40 \pm 0.01^{\mathrm{a}, \mathrm{b}, \mathrm{c}}$ \\
\hline
\end{tabular}

* = significantly different from Z. mays at $p<0.05 ; \mathrm{a}=$ significantly different from C. citrullus seed at $p<0.05$ $\mathrm{b}=$ significantly different from $C$. frutescens at $p<0.05 ; \mathrm{c}=$ significantly different from I. gabonensis at $p<0.05$ Values are expressed as mean $\pm \mathrm{SEM}, \mathrm{n}=3$ (where $\mathrm{SEM}=$ standard error of mean).

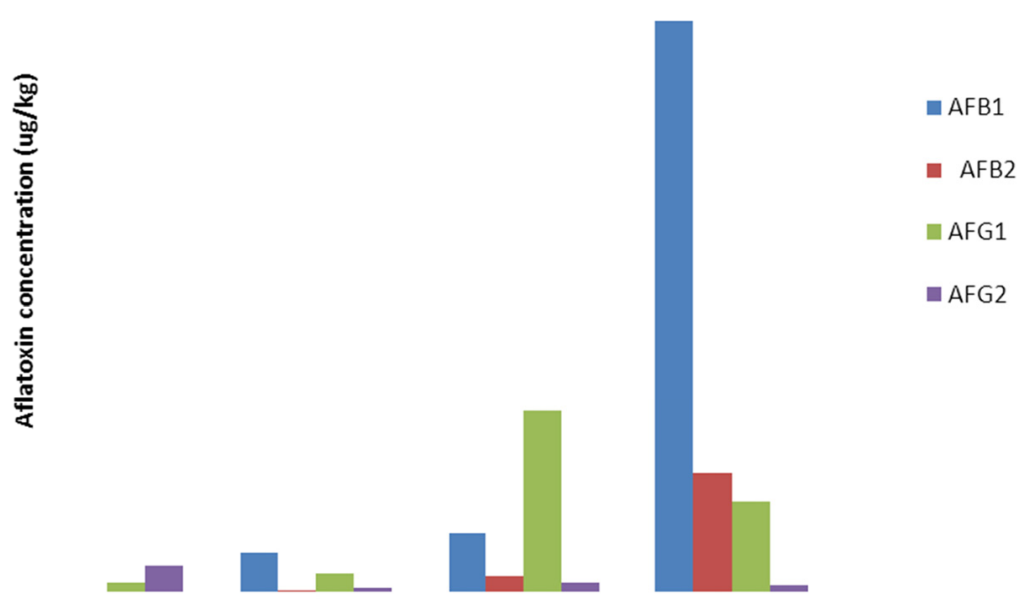

Figure 7. Aflatoxins $B_{1}, B_{2}, G_{1} \& G_{2}$ Concentration in the food samples ${ }^{*}=\mathrm{p}<0.05 \mathrm{vs}_{1} ; \mathrm{a}=\mathrm{p}<0.05 \mathrm{vs}_{2} ; \mathrm{b}=\mathrm{p}<0.05 \mathrm{vs} \mathrm{G}_{1}$; Values are expressed as mean \pm SEM, $\mathrm{n}=3$ (where SEM $=$ standard error of mean). 


\section{Discussion}

This study assayed for the total aflatoxin content and concentration of four aflatoxin types $\left(\mathrm{AFB}_{\mathrm{I}}, \mathrm{AFB}_{2}, \mathrm{AFG}_{1}\right.$, and $\mathrm{AFG}_{2}$ ) in five locally available food commodities commonly used in food preparation in Nigeria. The food materials were: common maize (Zea mays), melon seed (Colocynthis citrullus), red pepper (Capsicum frutescens), bush mango (Irvingia gabonensis) and groundnut (Arachis hypogea). The results showed that all $(100 \%)$ the food samples were contaminated with aflatoxin. It was further observed that except for bush mango and melon seeds, the levels of total aflatoxin in the food commodities were generally below the maximum allowable limits (10 $\mu \mathrm{g} / \mathrm{kg}$ for pepper, and $4 \mu \mathrm{g} / \mathrm{kg}$ for others) specified by the European Commission (AESAN, 2011), which is also currently being used by the National Agency for Food and Drug Administration and Control (NAFDAC), in Nigeria. This observation agrees with the findings from other studies (Adebayo-Tayo, Onilude, Ogunjobi, Gbolagade, \& Oladapo, 2006; Romagnoli, Meena, Gruppioni, \& Bergamini, 2007; Russell \& Peterson, 2007). However, levels of total aflatoxins below the levels found in the present study have also been reported in some foodstuffs (Zinedine et al., 2006).

The high levels of total aflatoxin found in some of the food materials used in this study may be attributed to some biotic and abiotic factors such as temperature, relative humidity, moisture content, food chemical composition, storage duration and insect attack. Studies by Simsek et al. (2002) showed that temperature favourable for aflatoxin production is $25-30{ }^{\circ} \mathrm{C}$ and relative humidity $97-99 \%$. Also, Ross et al. (1979) had earlier reported that if both temperature $\left(20-38^{\circ} \mathrm{C}\right)$ and moisture (16-24\%) are favourable for Aspergillus flavus, aflatoxin can be produced within 48 hours.

The level of moisture found in some of the food materials used in this study may be responsible for the growth of microorganisms with subsequent production of aflatoxins. Smith and Moss (1995) had shown that moisture determines whether microbes can colonize a substrate or not. The high moisture content in some of the food materials used in this study may be as a result of high humidity $(>70 \%)$ and high temperature $(>25 \%)$, which are characteristic of the tropical and sub-tropical regions of the world where Nigeria is located.

Also in this study, bush mango showed the highest level of total aflatoxin, followed by red pepper, melon seed and groundnut, while maize had the least. The trend in the occurrence of aflatoxins in these food samples is directly proportional to their moisture contents. It is therefore most probable that the differences in the moisture content of these food materials were responsible for the levels of total aflatoxin found in them. Maize which had the least moisture content also had the lowest total aflatoxin content. According to Sakai et al. (1984) and Schetzki and Ong (2001), substrate chemical composition is an important factor in aflatoxin contamination. Maize is a commodity with low lipid content while bush mango, melon seed and groundnut are oil seeds and contain high levels of lipid. It is relatively easier to dehydrate a food commodity with low lipid content than that with high lipid content. Hence, a higher level of moisture in the bush mango, melon seed and groundnut, leading to higher levels of total aflatoxins in them than in maize. In this study, a statistical correlation was found between aflatoxin concentration and moisture content of the food samples.

The results of this study also showed that $\mathrm{AFB}_{1}, \mathrm{AFB}_{2}, \mathrm{AFG}_{1}$ and $\mathrm{AFG}_{2}$ were unequally distributed in the five food samples examined. None of the aflatoxin types was detected in the groundnut, while the maize sample contained only $\mathrm{AFG}_{1}$ and $\mathrm{AFG}_{2}$. The bulk of the aflatoxin species were found in the bush mango and red pepper samples. This variation in occurrence e of the various aflatoxin types may be attributable to differences in the chemical composition of the food commodities used in the study. Such differences in food chemical composition leading to variation in aflatioxin content have been reported by Schatzki and Ong (2001). The food chemicals could interact with some environmental factors to bring about differences in the growth of microbes and in the subsequent formation of aflatoxins in the various commodities. These environmental factors include excessive moisture in the field, storage temperature, humidity, drought, variations in harvesting practices and insect infestations. These factors have been shown to determine the severity of mycotoxin contamination of foodstuffs (Hussein \& Brassel, 2001).

It is however surprising that the groundnut samples used in this study did not show any detectable levels of the aflatoxin types assayed, especially $\mathrm{AFB}_{1}$. A near similar observation was also made on the maize sample, which showed detectable levels of contamination only with the $\mathrm{AFG}_{1}$ and $\mathrm{AFG}_{2}$. Studies in other locations within and outside Nigeria have shown high levels of aflatoxin contamination in groundnut, the commonest being aflatoxin $\mathrm{B}_{1}$ (Williams et al., 2004; Jimoh \& Kolapo, 2008; Kamika, 2012; Oranusi \&Olarewaju, 2013). Also, it has been demonstrated that maize is one of the most commonly contaminated foods with aflatoxins (Williams et al., 2004; Muthomi, Njenga, Gathumbi, \& Cheminingwa, 2009; Oranusi \& Olarewaju, 2013). For instance in Nairobi, Kenya, an outbreak of aflatoxicosis resulting in the death of 125 of the 317 (39.4\%) cases reported was traced to 
the contamination of maize and its products from retail shops (Muture \& Ogana, 2005; Muthomi et al., 2009). However, Scussel and Baratto (1994) in their studies on the aflatoxin levels in grains including maize from Brazil did not find any detectable levels of the four aflatoxin types assayed in this work. These researchers attributed their findings to improved harvesting and storage practices, as well as weather during that particular year. It is most probable that these factors were responsible for the results obtained in this work moreso, since the various foodstuffs were collected in January, which in Calabar - Nigeria is a period of dry season when the relative humidity is generally low.

The high levels of contamination of bush mango with aflatoxins $B_{1}, B_{2}, G_{1}$ and $G_{2}$ observed in the present study agrees with the findings by Adebayo-Tayo et al. (2006) in some samples of bush mango (Irvingia gabonensis) examined in some markets in Akwa Ibom State, Nigeria. This was attributed to a number of factors including possible infection of the bush mango during cracking/ de-shelling to extract the cotyledons, drying, sorting as well as transportation. Akwa Ibom State shares a common boundary with Cross River State where this study took place, with similar climatic and socio-cultural features. It is therefore possible that all or some of these factors were responsible for the high levels of the aflatoxin types found in the bush mango samples in the present study.

Melon seed has also been reported (Bankole \& Joda, 2004) to contain a level of $\mathrm{AFB}_{1}$ similar to the results of this study. Also, this study obtained some levels of the four aflatoxin types in the red pepper. Studies by Aydin et al. (2007) had found aflatoxin $B_{1}$ in red pepper even though the levels in some of the samples collected were below the maximum tolerable limit. This could possibly be as a result of differences in the chemical composition of the food substrates. It is possible that different aflatoxin types have preference for certain foods depending on their chemical composition.

\section{Conclusions}

The results of our investigation demonstrate that the aflatoxigenic fungus (Aspergillus) aided by moisture and other factors is a common agent of contamination of foodstuffs marketed in Calabar. However, the levels of total aflatoxin in most of the food commodities are within acceptable limits and not all of them contain the $B_{1}, B_{2}, G_{1}$ or $\mathrm{G}_{2}$ aflatoxins. The total and individual aflatoxin levels in the bush mango were generally above the maximum allowable limits of NAFDAC. Reduction of aflatoxin levels in food ingredients in Calabar and indeed Nigeria especially in bush mango should be a public health priority.

\section{References}

Adebayo-Tayo, B. C., Onilude, A. A., Ogunjobi,, A. A., Gbolagade, J. S., \& Oladapo, M. O. (2006). Detection of fungi and aflatoxin in shelved bush mango seeds (Irvingia sp.) stored for sale in Uyo, Nigeria. African Journal of Biotechnology, 5, 1729-1732

AESAN. (2011). Report of the Scientific Committee of the Spanish Agency for Food Safety and Nutrition (AESAN) in relation to the effect on the Spanish population of the derogation of national regulation on maximum allowed limits for aflatoxins $\mathrm{B}_{1}, \mathrm{~B}_{2}, \mathrm{G}_{1} \& \mathrm{G}_{2}$ in food (pp. 1-16).

AOAC. (2006). Natural toxins. In Official methods of analysis of AOAC International. (18th ed., pp. 1-89). AOAC. International, Gaithersburg.

Aydin, A., Erkan, M. E., Baskaya, R., \& Cfticioglu, G. (2007). Determination of aflatoxin $\mathrm{B}_{1}$ in powdered red pepper. Food Control, 18, 1015-1018. http://dx.doi.org/10.1016/j.foodcont.2006.03.013

Ayar, A., Sert, D., \& Con, A. A. (2007). Study on the occurrence of aflatoxin in raw milk due to feeds. Journal of Food Safety, 27, 199-207. http://dx.doi.org/10.1111/j.1745-4565.2007.00072.x

Bankole, S. A., \& Joda, A. O. (2004). Effect of lemon grass (Cymbopogon citratus) powder and essential oil on mould deterioration and aflatoxin contamination of melon seeds (Colocynthis citrullus L.). African Journal of Biotechnology, 3(1), 52-59. http://dx.doi.org/10.5897/AJB2004.000-2009

Eaton, D. L., \& Groopman, J. D. (1994). The toxicology of aflatoxins (pp. 392-426). New York: Academic Press. http://dx.doi.org/10.1016/B978-0-12-228255-3.50005-2

Herzallah, S. (2009). Determination of aflatoxins in eggs, milk, meat and meat products using HPLC fluorescent and UV detectors. Food Chemistry, 114(3), 1141-1146. http://dx.doi.org/10.1016/j.foodchem.2008.10.077

Hosseini, S., \& Bagheri, R. (2012). Some major mycotoxins and their mycotoxicoses in nuts and dried fruits. International Journal of Agronomy and Plant Production, 3(5), 179-184.

Hussein, S. \& Brassel, J. (2001). Toxicity, metabolism, and impact of mycotoxins on humans and animals. 
Toxicology, 167, 101-134. http://dx.doi.org/10.1016/S0300-483X(01)00471-1

Jimoh, K. O., \& Kolapo, A. L. (2008). Mycoflora and aflatoxin production in market samples of some selected Nigerian foodstuffs. Research Journal of Microbiology, 3, 169-174. http://dx.doi.org/10.3923/jm.2008.169.174

Kamika, I. (2012). Determination of aflatoxins in peanut (Arachis hypogea L.) collected from Kinshasa, Democratic Republic of Congo and Pretoria, South Africa: a comparative review. Masters Degree Dissertation, University of South Africa.

Muthomi, J. W., Njenga, L. N., Gathumbi, J. K., \& Cheminingwa, G. N. (2009). The occurrence of aflatoxins in maize and distribution of mycotoxin-producing fungi in Eastern Kenya. Plant Pathology Journal, 8(3), 113-119. http://dx.doi.org/10.3923/ppj.2009.113.119

Muture, B. N., \& Ogana, G. (2005). Aflatoxin levels in maize and maize products during the 2004 food poisoning outbreak in Eastern Province of Kenya. East African Medical Journal, 82(6), 275-279. http://dx.doi.org/10.4314/eamj.v82i6.9296

Olayiwola, I. O., Oganah, B. C., Oguntona, C. R. B., Popoola, A. R., Sanni, S. A., \& Sam-Wobo, S.O. (2013). Discourse Journal of Agriculture and Food Sciences, 1(5), 93-96.

Oranusi, S. U., \& Olarewaju, S. A. (2013). Mycoflora and aflatoxin contamination of some foodstuffs. International Journal of Biotechnology and Allied Fields, 1(1), 9-18.

Romagnoli, B., Meena, V., Gruppioni, N., \& Bergamini, C. (2007). Aflatoxins in spices, aromatic herbs, herb teas and medicinal plants marketed in Italy. Food Control, 18, 697-701. http://dx.doi.org/10.1016/j.foodcont.2006.02.020

Ross, I. J., Loewer, J. O., \& White, G. M. (1979). Potential for aflatoxin development in low temperature drying systems. American Society of Agricultural Engineers Paper 2, 12-18.

Russell, R., \& Peterson, M. (2007). Aflatoxin contamination in chilli from Pakistan. Food Control, 18, 817-820. http://dx.doi.org/10.1016/j.foodcont.2006.04.005

Sakai, T., Sugihara, K., \& Kozuka, H. (1984). Growth and aflatoxin production of Aspergillus parasiticus in plant materials. Journal of Hygienic Chemistry, 30, 62-68. http://dx.doi.org/10.1248/jhs1956.30.2_62

Schatzki, T. F., \& Ong, M. S. (2001). Dependence of aflatoxin in almonds on the type and amount of insect damage. Journal of Agricultural and Food Chemistry, 49, 4513-4519. http://dx.doi.org/10.1021/jf010585w

Scussel, V. M. \& Baratto, W. R. (1994). Levels of aflatoxins in grains from Santa Catarina State, Southern Brazil. Proceedings of the $6^{\text {th }}$ International working conference on stored-product protection (pp. 1051-1053).

Shepherd, G. S. (2008). Determination of mycotoxins in human food. Chemical Society Review, 37, 2468-2477. http://dx.doi.org/10.1039/b713084h

Simsek, O. Arici, M., \& Demir, C. (2002). Mycoflora of hazelnut (Corylus avellana L.) and aflatoxin content in hazelnut kernels artificially infected with Aspergillus parasiticus. Nahrung, 46, 194-196. http://dx.doi.org/10.1002/1521-3803(20020501)46:3<194::AID-FOOD194>3.0.CO;2-D

Smith, J. E., \& Moss, M. O. (1995). Mycotoxins Formation, Analysis and Significance (p. 148). Wiley \& Sons, Chichester.

Smith, J. E., Solomons, G. L., Lewis, C. W., \& Anderson, J. G. (1994). Mycotoxins in human nutrition and health. EC Directorate-General for Science, Research and Development, Agro-Industial Research Division, Brussels, Belgium.

SP-IPM. (2009). Advances in preventing and managing contaminants in food, feeds and the Environment. IPM Research Brief No. 7. SP-IPM Secretariat, International Institute of Tropical Agriculture (IITA), Ibadan, Nigeria, pp. 40.

WHO. (2002). World Health Organisation Global strategy for food safety: safer food for better health, food safety programme, Geneva, Switzerland.

Williams, J. H., Phillips, T. D., Jolly, P. E., Stiles, J. K., Jolly, C. M., \& Aggarwal, D. (2004). Human aflatoxicosis in developing countries: a review of toxicology, exposure, potential health consequences and interventions. American Journal of Clinical Nutrition, 80, 1106-1122.

Wu, F. (2007). Measuring the economic impacts of Fusarium toxins in animal feeds. Animal Feed Science and Technology, 137(3-4), 363-374. http://dx.doi.org/10.1016/j.anifeedsci.2007.06.010 
Zinedine, A., Brera, C., Elakhdari, C., Catano, C., Debegnachi, F., Angelini, S., ... Miraglia, M. (2006). Natural occurrence of mycotoxins in cereals and spices commercialized in Morocco. Food Control, 17, 868-874. http://dx.doi.org/10.1016/j.foodcont.2005.06.001

\section{Copyrights}

Copyright for this article is retained by the author(s), with first publication rights granted to the journal.

This is an open-access article distributed under the terms and conditions of the Creative Commons Attribution license (http://creativecommons.org/licenses/by/3.0/). 